\section{Impact of Material Shade and Distance from Light Curing Unit Tip on the Depth of Polymerization of Composites}

André L. Faria-e-Silva ${ }^{1}$, Christopher Fanger ${ }^{2}$, Lillian Nguyen², Demetri Howerton², Carmem S. Pfeifer ${ }^{3}$

\author{
'Department of Dentistry, \\ UFS - Universidade Federal de \\ Sergipe, Aracaju, SE, Brazil \\ ${ }^{2}$ School of Dentistry, Oregon Health \& \\ Science University, Portland, OR, USA \\ ${ }^{3}$ Department of Restorative Dentistry, \\ Division of Biomaterials and \\ Biomechanics, Oregon Health \& \\ Science University, Portland, OR, USA
}

Correspondence: André Luis Fariae-Silva, Rua Claudio Batista $s / n$, 49060-100, Aracaju, SE, Brazil. Tel: +55-79-2105.1824, e-mail: fariaesilva.andre@gmail.com

Key Words: Composite resins; curing lights, polymerization.

\section{Introduction}

Composite resins are largely used worldwide to restore both anterior and posterior teeth with high success rates $(1,2)$. The annual failure rate of posterior composite restorations is as low as $2.0 \%$ and most failures are related to the presence of recurrent caries, and to fracture of the material or tooth structure (3). Increased annual failure rates (up to 4\%) have been reported for composite restorations in anterior teeth, but in those cases re-interventions due to aesthetic reasons are also accounted for (4). The longevity of composite restoration depends on several factors, including the bonding to the tooth substrate and the mechanical strength of the material, which in turn depends on proper polymerization. Currently available materials for direct restorations are strictly photo-activated, since this allows for polymerization on command and complete control of working time by the clinician. However, the degree of conversion depends on the emission spectra of light curing units matching the absorption spectra of photo-initiators used in these materials $(5,6)$ and on the light actually reaching all portions of the restoration (7-9). In other words, light transmission directly affects the properties of a composite, and ultimately the restoration performance.

Many factors related to the material can affect light transmission through a composite, such as the thickness of the increment, and several optical properties, including the refractive index mismatch between the organic matrix and inorganic filler, the size and distribution of filler particles and the addition of pigments (10). For example, light scattering is known to be greater in materials with higher filler concentration, and with larger filler $(11,12)$. In addition, light scattering also increases in materials where the mismatch between refractive indices of the organic and inorganic portions is greater (7). More recently, manufacturers have included different pigments in their formulations to mimic the natural appearance of the tooth structure in terms of shade, fluorescence and opalescence. The range of shades now available to the clinician is very broad and encompasses opaque versions capable of masking discolorations, as well as very light shades to match teeth that have undergone whitening treatments (13). All of these are expected to affect the light transmission through the restoration.

In relation to the light source, the factors affecting light transmission include: the actual amount of photons reaching the material, expressed as energy per area or irradiance $\left(\mathrm{mW} / \mathrm{cm}^{2}\right)$, the wavelength emission spectra and the beam distribution. Most light-curing units (LCU) available on the market deliver irradiances as high as 1,000 
$\mathrm{mw} / \mathrm{cm}^{2}$, with some examples going far beyond that, which has been shown to provide adequate levels of degree of conversion for the composite in most clinical situations (14). However, very often the access for the light guide is compromised to some extent, as is the case on the bottom of the proximal box of class II restorations from Black classification, especially when considering distal boxes in posterior teeth in the upper arch, for example. In such situations, the positioning of the light tip is compromised, and the amount of light delivered to the composite is less than optimal $(15,16)$. Studies have shown that in those situations, light attenuation can be in the order of $68-83 \%$ (17), and that reflects in compromised mechanical properties (15). Since the longevity of composite restorations is largely dependent on the proper polymerization of the restorative material, it is important to determine the quality of the light being transmitted through the composite and the conversion achieved by this material in its entire thickness, so that reliable restorative protocols can be established.

Therefore, the aim of this study was to evaluate the effect of the composite shade and the distance from the light-curing unit (LCU) on the irradiance reaching the bottom of composite disks on the depth of polymerization. The hypotheses of study were than both distance from LCU tip and composite shade would affect the depth of polymerization.

\section{Material and Methods}

This in vitro investigation was conducted using a $2 \times$ 3 factorial study design to evaluate the factors 'distance from LCU tip' in two levels $(0$ or $1.0 \mathrm{~cm}$ ) and 'composite shade' in three levels. The nano-hybrid composite Venus Diamond (Heraeus Kulzer, GmbH, Gemrnay) was evaluated at following shades: Opaque Extra Dark Chromatic (OXDC), Bleach Extra Light (BXL, for bleached teeth), and the universal shade $\mathrm{A} 2$.

In order to assess the ability of light to penetrate through each composite shade, a portable spectrometerbased instrument (CheckMARC, BlueLight Analytics, Halifax, NS, Canada) was used to assess the irradiance reaching the bottom of composite disks. Unpolymerized composites were inserted into silicon molds $(3.0 \mathrm{~mm}$ in diameter, $3.0 \mathrm{~mm}$ in thickness) between two polyester strips and then, placed over the top surface sensor of the spectrometer. The tip of an LED unit (Bluephase, Ivoclar-Vivadent, Amherst, NY, USA) was positioned contacting the surface of the upper polyester strip (distance of $0 \mathrm{~cm}$ ) or $1.0 \mathrm{~cm}$ above this surface. During the entire time of photo-activation (30 s), the irradiance of light reaching the sensor through the $3-m m$ thickness of the composite was recorded $(n=3)$. The irradiances reaching the spectrometer sensor without any interposition of composite disks were also measured for each distance from the LCU tip. This allowed us to calculate the percentage of irradiance lost due to interposition of composite disks, as well as the effect of the distance from the tip on the irradiance reaching the specimen. The confidence interval was set at 95\% for the irradiance measured at each experimental condition.

In order to map the degree of conversion achieved at different depths from irradiated surface, the composites were inserted into silicon molds ( $2 \mathrm{~mm}$ long $\times 2 \mathrm{~mm}$ wide x $4 \mathrm{~mm}$ thick), covered with a glass slide and photoactivated under the same conditions described for the previous experiment $(n=3)$. The specimens were stored in dark container for $24 \mathrm{~h}$ at $37^{\circ} \mathrm{C}$. Previous research has shown that after $24 \mathrm{~h}$ there is no significant increase in the conversion (17). The specimens were then removed from the mold and embedded into gypsum blocks. The blocks were sectioned using a diamond saw (Accutom-5, Struers, Cleveland, $\mathrm{OH}$ ) to obtain three $0.4 \mathrm{~mm}$ thick slices parallel to the long axis of each specimen. The slices were positioned over the platform of the IR microscope (Nicolet Continu um FIIR Microscope) connected to the spectrometer Thermo Nicolet 6700 (Thermo Scientific, Pittsburgh, PA, USA). Degree of conversion in depth was mapped using the motorized stage through the $4 \mathrm{~mm}$ length in transmission. For each slice, three spectra per depth for eight different depths were collected in 500- $\mu \mathrm{m}$ steps using aperture of 100 $\mu \mathrm{m}, 32$ scans/spectrum, $4 \mathrm{~cm}^{-1}$ resolution. Conversion was calculated taking into account the vinyl peak area at 6165 $\mathrm{cm}^{-1}$ normalized by an internal reference (aromatic peak area at $4625 \mathrm{~cm}^{-1}$ ). Spectra of unpolymerized composites were also collected and used to calculate de degree of conversion. The average of degree of conversion measured at each specimen (means from three slices) was calculated and used in the statistical analysis. The confidence interval at $95 \%$ was used for the degree conversion obtained at different depths for each experimental condition.

\section{Results}

Results for the mean irradiance measured at the bottom of $3 \mathrm{~mm}$ specimens at the end of a photo-activation time are displayed in Table 1. Photo-activating the specimens with the tip contacting the surface resulted in highest irradiance only for A2, whereas the distance of tip did not affect the irradiance transmitted through disks of others shades. Interposing OXDC disks resulted in lowest values of irradiance, whereas the highest values were observed when A2 disks were used. The irradiance lost due to composite disks interposition ranged from 91.4 to $99.3 \%$.

The results of depth of polymerization are presented in Table 2 and Figure 1. In general, differences among the composites shades only were observed at depths greater than $1.5 \mathrm{~mm}$ from the irradiated surface. Beyond this depth, 
a trend was observed for highest and lowest values of DC for shades A2 and OXDC, respectively. For all composite shades, a trend in reduction of the DC towards the bottom of the specimen was observed, while a more evident slope occurred for OXDC, followed by BXT. Almost no conversion was measured for OXDC beyond 3.5 and $3.0 \mathrm{~mm}$ from the surface when the tip of LED was kept at 0 and $1 \mathrm{~mm}$ from the composite surface, respectively.

\section{Discussion}

The distance from the tip of the light guide in relation

Table 1. Averages $(95 \% \mathrm{CI})$ of mean irradiance in $\mathrm{mW} / \mathrm{cm}^{2}$ measured during the entire time of light-activation $(n=3)$; and percentage of irradiance lost due to composites disk interposition or increasing on distance from LCU tip

\begin{tabular}{lcc}
\hline \multirow{2}{*}{ Composite shade } & \multicolumn{2}{c}{ Distance from LCU tip } \\
\cline { 2 - 3 } & $0 \mathrm{~cm}$ & $1 \mathrm{~cm}$ \\
\hline \multirow{2}{*}{ 2 } & $50.0(41.9-58.1)$ & $30.7(26.2-35.2)$ \\
& $91.4 \%^{1}$ & $92.9 \% 0^{1}$ \\
BXL & $23.0(21.1-24.9)$ & $23.0(20.1-25.9)$ \\
& $96.0 \% 0^{1}$ & $94.7 \% 0^{1}$ \\
OXDC & $4.3(2.7-5.5)$ & $4.0(2.9-5.1)$ \\
Without composite & $580.3(567.9-592.7)$ & $931.7(416.4-447.0)$ \\
interposition & - & $25.6 \% \%^{2}$ \\
\hline
\end{tabular}

CI: Confidence interval; LCU: Light-curing unit. 1. Percentage of irradiance

$\checkmark$ lost regarding the average measured at same distance of tip but without composite disks interposition; 2. Percentage of irradiance lost due to increasing on distance from LCU tip.

Table 2. Means (95\% CI) for degree of conversion (\%) measured at different depths from the irradiated surface for each composite shade (A2, BXL, OXDC) and distance from tip $(0$ and $1 \mathrm{~cm})$ during the photo-activation $(\mathrm{n}=3)$

\begin{tabular}{|c|c|c|c|c|c|c|}
\hline \multirow{3}{*}{$\begin{array}{l}\text { Depth from } \\
\text { irradiated } \\
\text { surface }(\mathrm{mm})\end{array}$} & \multicolumn{6}{|c|}{ Distance from LCU tip } \\
\hline & \multicolumn{3}{|c|}{$0 \mathrm{~cm}$} & \multicolumn{3}{|c|}{$1 \mathrm{~cm}$} \\
\hline & A2 & BXL & OXDC & $\mathrm{A} 2$ & BXL & OXDC \\
\hline 0.5 & $\begin{array}{c}73.5 \\
(73.0-74.0)\end{array}$ & $\begin{array}{c}71.4 \\
(68.0-74.8)\end{array}$ & $\begin{array}{c}70.9 \\
(68.1-73.6)\end{array}$ & $\begin{array}{c}71.4 \\
(65.6-77.2)\end{array}$ & $\begin{array}{c}72.2 \\
(70.3-74.1)\end{array}$ & $\begin{array}{c}68.6 \\
(59.7-77.6)\end{array}$ \\
\hline 1.0 & $\begin{array}{c}73.3 \\
(72.3-74.3)\end{array}$ & $\begin{array}{c}72.2 \\
(68.2-76.2)\end{array}$ & $\begin{array}{c}69.2 \\
(63.6-74.9)\end{array}$ & $\begin{array}{c}69.6 \\
(64.9-74.3)\end{array}$ & $\begin{array}{c}71.5 \\
(69.3-73.7)\end{array}$ & $\begin{array}{c}66.8 \\
(64.2-69.3)\end{array}$ \\
\hline 1.5 & $\begin{array}{c}73.8 \\
(73.4-74.1)\end{array}$ & $\begin{array}{c}70.8 \\
(64.9-76.6)\end{array}$ & $\begin{array}{c}64.2 \\
(57.6-70.8)\end{array}$ & $\begin{array}{c}70.1 \\
(64.2-76.0)\end{array}$ & $\begin{array}{c}69.3 \\
(68.0-70.6)\end{array}$ & $\begin{array}{c}60.9 \\
(58.1-63.7)\end{array}$ \\
\hline 2.0 & $\begin{array}{c}72.3 \\
(71.7-72.9)\end{array}$ & $\begin{array}{c}68.7 \\
(62.5-75.0)\end{array}$ & $\begin{array}{c}50.4 \\
(41.0-59.8)\end{array}$ & $\begin{array}{c}67.2 \\
(61.2-73.2)\end{array}$ & $\begin{array}{c}67.3 \\
(64.6-70.0)\end{array}$ & $\begin{array}{c}36.7 \\
(31.7-41.7)\end{array}$ \\
\hline 2.5 & $\begin{array}{c}70.4 \\
(69.4-71.5)\end{array}$ & $\begin{array}{c}63.2 \\
(53.9-72.5)\end{array}$ & $\begin{array}{c}30.9 \\
(23.1-38.7)\end{array}$ & $\begin{array}{c}65.6 \\
(58.3-72.8)\end{array}$ & $\begin{array}{c}61.7 \\
(55.9-67.5)\end{array}$ & $\begin{array}{c}8.5 \\
(6.1-10.9)\end{array}$ \\
\hline 3.0 & $\begin{array}{c}68.2 \\
(65.6-70.8)\end{array}$ & $\begin{array}{c}48.7 \\
(41.8-55.6)\end{array}$ & $\begin{array}{c}15.9 \\
(11.0-20.8)\end{array}$ & $\begin{array}{c}63.0 \\
(56.8-69.2)\end{array}$ & $\begin{array}{c}35.2 \\
(26.6-43.8)\end{array}$ & $\begin{array}{c}0.9 \\
(0.0-0.7)\end{array}$ \\
\hline 3.5 & $\begin{array}{c}66.0 \\
(63.1-68.8)\end{array}$ & $\begin{array}{c}31.5 \\
(26.1-36.8)\end{array}$ & $\begin{array}{c}7.3 \\
(5.5-9.1)\end{array}$ & $\begin{array}{c}59.8 \\
(53.9-65.7)\end{array}$ & $\begin{array}{c}14.6 \\
(9.9-19.4)\end{array}$ & $\begin{array}{c}0.4 \\
(0.1-0.7)\end{array}$ \\
\hline 4.0 & $\begin{array}{c}58.5 \\
(55.2-61.8)\end{array}$ & $\begin{array}{c}21.3 \\
(15.1-27.5)\end{array}$ & $\begin{array}{c}1.9 \\
(0.0-3.8)\end{array}$ & $\begin{array}{c}44.9 \\
(41.2-48.6)\end{array}$ & $\begin{array}{c}5.1 \\
(0.6-9.6)\end{array}$ & $\begin{array}{c}0.1 \\
(0.0-0.1)\end{array}$ \\
\hline
\end{tabular}

CI: Confidence interval; LCU: Light-curing unit. to the composite surface is an important factor influencing the irradiance achieved at the composite surface and can be controlled by the clinician in some situations $(15,18,19)$. As the distance from the composite surface increases, a significant reduction on the irradiance reaching the composite can be expected due to the divergence of the beam from the tip of the light guide tip, as well as due to energy scattering as the light passes through the air $(15,18,20)$. During the restoration of class II preparations in posterior teeth, the placement of the light guide over the cusp tip usually results in 6-8 $\mathrm{mm}$ of distance between the LCU tip and the floor of a proximal box. In the present study, a longer distance of $10 \mathrm{~mm}$ was used, simulating a clinical scenario imposed by class II preparations (6 to $8 \mathrm{~mm}$ ) with the added distance caused by incorrect positioning of the LCU tip. Interestingly, a reduction of only around $25 \%$ on irradiance was observed when the tip was placed $10 \mathrm{~mm}$ away from the spectrometer sensor. This reduced drop on irradiance values $\mathrm{s}$ can be explained mainly by on beam homogeneity of LCU used in the present study. An interesting study using a beam profiler demonstrated that irradiance measured by spectrometers represents a wide range of irradiance values distributed across the light beam, and the distance affects the useful beam diameter (18). Thus, irradiance measured from more heterogeneous beams drops more drastically when the distance to the tip is increased. The LCU used in the present study presents a homogenous beam profile (14) which helps to explain the low values of irradiance lost due to increased distance from tip.

Surprisingly, the reduction on irradiance reaching the composite had limited effect on material conversion at the surface, regardless of the shade. The results of conversion indicated similar values close to composite surface between the photoactivation performed with the LCU tip placed over the strip and that carried out with the tip $1 \mathrm{~cm}$ away from the irradiated surface. 
When comparisons between the distances are made for the same composite shade, differences are only observed for depths greater than 2-mm, 3-mm and 4-mm for the shades OXDC, BXL and A2, respectively. Since composite increments no thicker than 2-mm are recommended to restore posterior preparations using incremental filling technique $(21,22)$, the placement of LCU tip up to 10-mm away from the material surface might not significantly affect the composite conversion, at least within the limitations of this study. In fact, according to the present results, the mean irradiance of $430 \mathrm{~mW} / \mathrm{cm}^{2}$ leads to up to $60.9-71.4 \%$ conversion of composite during 30s of photo-activation, which has been deemed to be a clinically acceptable level (23). However, it needs to be pointed out that only one light source was evaluated here, and generalizations involving different equipment need to be made with care.

Depth of polymerization is directly related to the amount of photons being transmitted through the material and reaching its deeper portions to activate the polymerization reaction (24). Therefore, polymerization in depth can be expected to be hampered in more opaque materials since light transmission in those cases is jeopardized (8). In addition, filler fraction, size and refractive index are all related to a material's translucency and, therefore, light scattering during polymerization $(7,11)$. In addition, the inherent shade of a composite material depends on the pigments that are incorporated in the matrix and with the fillers (10). In the present study, all composites are from the same manufacturer and present similar inorganic and monomeric compositions, and even though more specific compositional information is not provided by the manufacturer, it can be inferred that the different shades contain different types and amounts of pigments. According to the results of the present study, the A2 shade resulted in the highest irradiance reaching the spectrometer sensor after passing through the composite disks, whereas the lowest values were observed for OXDC. Irradiance reductions ranging from 25 to $54 \%$ were found when the shade BXL was compared to $A 2$, which was somewhat surprising, but can be speculated to be due to the addition of white pigments that allow the use of the BXL shade to restore bleached teeth. Higher irradiance reduction was observed for OXDC (ranging from 87 to $94 \%$ when compared to A2) since this composite is highly opaque and it is used to mask discolored substrates during esthetic restorations. Moreover, if the irradiated energy loss is calculated based on measurement performed without any composite interposition, less than $1 \%$ of light delivered by LCU reached the bottom of OXDC composite disks.

As expected, a reduction on conversion toward deeper areas was observed, with the more marked reduction being observed for the most opaque shade. Furthermore, significant differences among the composites shades was observed only for depths greater than 1.5- $\mathrm{mm}$, and almost no conversion was measured for OXDC beyond $2.5-\mathrm{mm}$. These results can be partially explained by the reduced energy dose (irradiance by time of photo-activation) reaching the composite to start the polymerization. Reciprocity law states that the polymerization of a given material is directly proportional to the energy dose, and for the same final energy delivered similar conversion is expected (25-27). Based on this statement, at 3-mm of depth when the LCU tip was placed $1 \mathrm{~cm}$ from the composite surface, the greater energy delivered for BXL $(\approx 0.9 \mathrm{~J} /$ $\left.\mathrm{cm}^{2}\right)$ compared to A2 $\left(\approx 0.6 \mathrm{j} / \mathrm{cm}^{2}\right)$ would result in improved conversion.

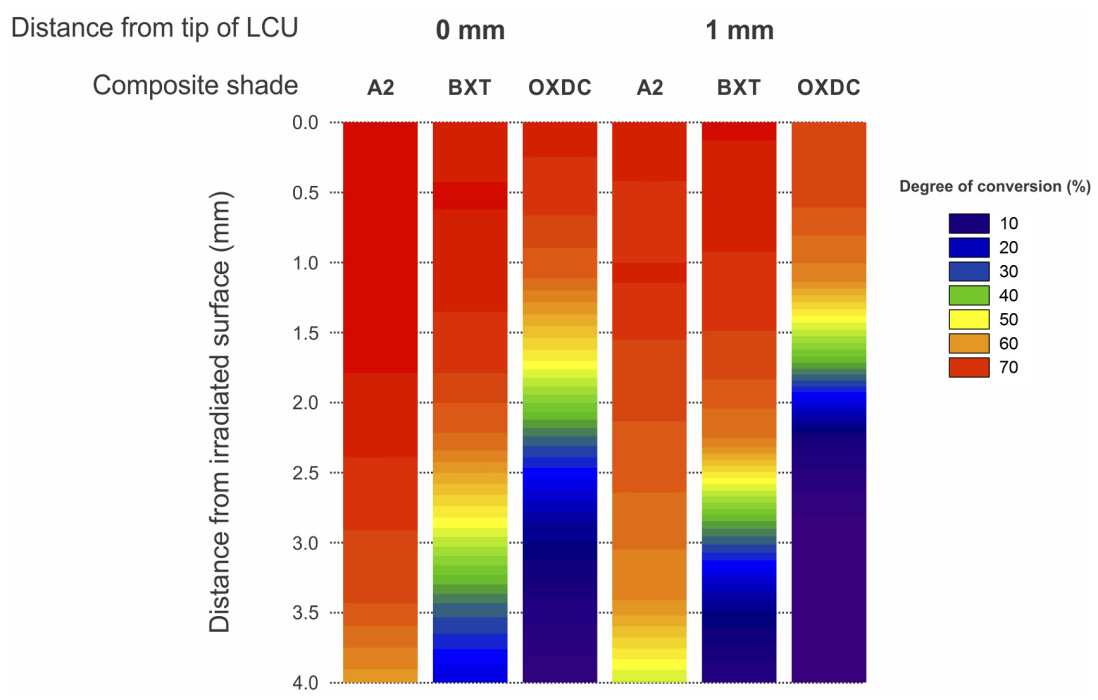

Figure 1. Heat maps of the average degree of conversion measured at different depths from irradiated surface for each composite shade light-cured with the tip of LED positioned at 0 or $1 \mathrm{~cm}$ from composite surface
However, higher conversion was observed for A2 ( $\approx 63 \%$; and $\approx 35 \%$ for $\mathrm{BXL})$ under this condition. This apparent anomaly might be related to the complex chain polymerization process involving methacrylate monomers, and demonstrates that the reciprocity law fails to fully explain the polymerization behavior of dental composites $(26,27)$.

The incremental composite filling technique has been recommended for many decades to ensure proper polymerization in depth and in theory reduce polymerization stress, but simpler and faster restorative protocols are preferable by clinicians. It has been reported that a number 
of increments as high as 16 might be used to restore a standardized mesio-oclusal-distal Class II cavity preparation using the incremental technique, depending on the clinician being surveyed (28). In an attempt to simplify the procedure, and reduce the opportunity for operator error, the concept of bulk-fill insertion has been developed and has gained popularity among the clinicians. This approach recommends the insertion of composites in increments up to 4-5 mm thick, using materials that are specifically designed to that end $(29,30)$. Modifications in filler content, the use of additional or more efficient photo-initiators, and/or the use of novel resin monomers and additives providing reduced stress are some of approaches used by manufacturers of bulk-fill composite to allow for the composite to be inserted using this technique $(31,32)$. However, the insertion of socalled conventional composites using increments thicker than 2-mm has been used and evaluated for quite some time $(32,33)$. As the results of the present study seem to suggest, the use of increments thicker than $2 \mathrm{~mm}$ might be possible for certain shades of composite. One limitation of the methodology used in the present study was that the irradiance was measured at 3-mm depth, whereas the conversion was assessed up to $4-\mathrm{mm}$. The reason was that the sensor of spectrometer used is unable to measure very low irradiances.

In conclusion, the findings of present study showed that increasing the distance of LCU tip from composite surface had limited effect on irradiance loss and degree of conversion, and significant modifications on this last outcome were only observed beyond 2-mm and 4-mm of depth for more opaque and translucent shades, respectively. On the other hand, the composite shade, which is related to translucency of material, had strong effect on irradiance reaching the bottom of composite and on depth of polymerization. Shade A2 presented the deeper polymerization and higher irradiance in the bottom of composite, whereas the lowest values of depth of polymerization and irradiance were found to OXDC.

\section{Resumo}

Este estudo objetivou avaliar o efeito da cor do compósito e da distância da ponta do aparelho fotopolimerizador (AFP) na irradiância alcançando a base do disco de compósito e na profundidade de polimerização. Compósitos de três cores (opaca - OXDC, clareado - BXL, e A2) foram inseridos em moldes com $3 \mathrm{~mm}$ de espessura posicionados sobre um espectrômetro e fotoativados com a ponta do AFP (Bluephase) colocada a 0 ou $1 \mathrm{~cm}$ da superficie do compósito. A irradiância média alcançando a base do compósito foi registrada durante toda a fotoativação (30 s). Amostras $(2 \times 2 \times 4 \mathrm{~mm})$ de compósito polimerizado também foram confeccionadas e usada para mapear o grau de conversão obtido em diferentes profundidades da superficie irradiada. As amostras foram seccionadas em fatias que foram posicionadas sobre a plataforma de um microscópio infra-vermelho conectado ao espectrômetro para mapear a conversão. A conversão foi mensurada em oito diferentes profundidades com 500- $\mu \mathrm{m}$ entre elas. Aumentando a distância da ponta do AFP reduziu a irradiância apenas para A2. Interpondo discos de OXDC resultou em menores valores de irradiância e A2 nos maiores. Uma tendência de redução na conversão foi observada em direção a base das amostras para todas as condições experimentais, com uma redução mais acentuada para OXDC. Diferenças entre as cores e distâncias da ponta do AFP foram evidentes apenas a partir de 1,2-2,0 mm de profundidade. Como conclusão, tanto a cor do compósito como a distância da ponta do AFP podem afetar a transmissão de luz e a profundidade de polimerização, enquanto que 0 efeito do último foi mais pronunciado.

\section{Acknowledgements}

The authors thank BlueLight analytics for providing the CheckMARC equipment for use in this study and Heraeus Kulzer for the donation of composites. ALFS is grateful to Capes/Brazil for scholarship (99999.006169/2014-07). CSP thanks NIH-NIDCR for funding (K02 DE 025280).

\section{References}

1. Lynch $C D$, Shortall AC, Stewardson D, Tomson PL, Burke FJ. Teaching posterior composite resin restorations in the United Kingdom and Ireland: consensus views of teachers. Br Dent J 2007;203:183-187.

2. Demarco FF, Corrêa MB, Cenci MS, Moraes RR, Opdam NJ. Longevity of posterior composite restorations: not only a matter of materials. Dent Mater 2012;28:87-101.

3. Opdam NJ, van de Sande FH, Bronkhorst $E$, Cenci MS, Bottenberg $P$, Pallesen U, Gaengler P, Lindberg A, Huysmans MC, van Dijken JW. Longevity of posterior composite restorations: a systematic review and meta-analysis. J Dent Res 2014;93:943-949.

4. Demarco FF, Collares $K$, Coelho-de-Souza FH, Correa MB, Cenci MS, Moraes RR, Opdam NJ. Anterior composite restorations: A systematic review on long-term survival and reasons for failure. Dent Mater 2015;31:1214-1224.

5. Pfeifer CS, Ferracane JL, Sakaguchi RL, Braga RR. Photoinitiator content in restorative composites: influence on degree of conversion, reaction kinetics, volumetric shrinkage and polymerization stress. Am J Dent 2009;22:206-210.

6. Salgado VE, Albuquerque PP, Cavalcante LM, Pfeifer CS, Moraes RR, Schneider LF. Influence of photoinitiator system and nanofiller size on the optical properties and cure efficiency of model composites. Dent Mater 2014;30(10):e264-e271.

7. Shortall AC, Palin WM, Burtscher P. Refractive index mismatch and monomer reactivity influence composite curing depth. J Dent Res 2008;87:84-88.

8. del Mar Pérez M, Saleh A, Pulgar R, Paravina RD. Light polymerizationdependent changes in color and translucency of resin composites. Am J Dent 2009;22:97-101.

9. Ilie N, Durner J. Polymerization kinetic calculations in dental composites: a method comparison analysis. Clin Oral Investig 2014;18:1587-1596.

10. Mikhail SS, Schricker SR, Azer SS, Brantley WA, Johnston WM. Optical characteristics of contemporary dental composite resin materials. J Dent 2013;41:771-778.

11. Emami N, Sjödahl M, Söderholm KJ. How filler properties, filler fraction, sample thickness and light source affect light attenuation in particulate filled resin composites. Dent Mater 2005;21:721-730

12. Fujita K, Ikemi T, Nishiyama N. Effects of particle size of silica filler on polymerization conversion in a light-curing resin composite. Dent Mater 2011;27:1079-1085.

13. Villarroel M, Fahl N, De Sousa AM, De Oliveira OB Jr. Direct esthetic restorations based on translucency and opacity of composite resins. J Esthet Rest Dent 2011;23:73-87.

14. Shimokawa CA, Turbino ML, Harlow JE, Price HL, Price RB. Light output from six battery operated dental curing lights. Mater Sci Eng C Mater Biol Appl 2016;69:1036-1042.

15. Price RB, Felix CA, Andreou P. Effects of resin composite composition and irradiation distance on the performance of curing lights. Biomaterials. 2004;25:4465-4477. 
16. Corciolani G, Vichi A, Davidson CL, Ferrari M. The influence of tip geometry and distance on light-curing efficacy. Oper Dent 2008;33:325-331.

17. Inokoshi $M$, Pongprueksa $P$, De Munck J, Zhang $F$, Vanmeensel $K_{\text {, }}$ Minakuchi S, Vleugels J, Naert I, Van Meerbeek B. Influence of Light Irradiation Through Zirconia on the Degree of Conversion of Composite Cements. J Adhes Dent 2016;18:161-171

18. Price RB, Labrie $D$, Whalen JM, Felix CM. Effect of distance on irradiance and beam homogeneity from 4 light-emitting diode curing units. J Can Dent Assoc 2011;77:69.

19. Price RB, Strassler HE, Price HL, Seth S, Lee CJ. The effectiveness of using a patient simulator to teach light-curing skills. J Am Dent Assoc 2014;145:32-43.

20. Prati C, Chersoni S, Montebugnoli L, Montanari G. Effect of air, dentin and resin-based composite thickness on light intensity reduction. Am J Dent. 1999;12:231-234

21. Campodonico CE, Tantbirojn D, Olin PS, Versluis A. Cuspal deflection and depth of cure in resin-based composite restorations filled by using bulk, incremental and transtooth-illumination techniques. J Am Dent Assoc 2011;142:1176-1182.

22. Harlow JE, Rueggeberg FA, Labrie D, Sullivan B, Price RB. Transmission of violet and blue light through conventional (layered) and bulk cured resin-based composites. J Dent 2016;53:44-50.

23. Rueggeberg FA, Caughman WF, Curtis JW Jr. Effect of light intensity and exposure duration on cure of resin composite. Oper Dent 1994;19:26-32.

24. Chen YC, Ferracane JL, Prahl SA. Quantum yield of conversion of the photoinitiator camphorquinone. Dent Mater 2007;23:655-664

25. Leprince JG, Hadis M, Shortall AC, Ferracane JL, Devaux J, Leloup G, et al. Photoinitiator type and applicability of exposure reciprocity law in filled and unfilled photoactive resins. Dent Mater 2011;27:157-164.
26. Hadis M, Leprince JG, Shortall AC, Devaux J, Leloup G, Palin WM. High irradiance curing and anomalies of exposure reciprocity law in resinbased materials. J Dent 2011;39:549-557.

27. Wydra JW, Cramer NB, Stansbury JW, Bowman CN. The reciprocity law concerning light dose relationships applied to BisGMA/TEGDMA photopolymers: theoretical analysis and experimental characterization. Dent Mater 2014;30:605-612.

28. Bicalho AA, Pereira RD, Zanatta RF, Franco SD, Tantbirojn D, Versluis A, Soares CJ. Incremental filling technique and composite material - part I: cuspal deformation, bond strength, and physical properties. Oper Dent 2014;39:E71-E82.

29. van Dijken JW, Pallesen U. Randomized 3-year clinical evaluation of Class I and II posterior resin restorations placed with a bulk-fill resin composite and a one-step self-etching adhesive. J Adhes Dent 2015;17:81-88.

30. Van Ende A, De Munck J, Lise DP, Van Meerbeek B. Bulk-Fill Composites: A Review of the Current Literature. J Adhes Dent 2017;19:95-109.

31. Alshali RZ, Salim NA, Sung R, Satterthwaite JD, Silikas N. Qualitative and quantitative characterization of monomers of uncured bulk-fill and conventional resin-composites using liquid chromatography/mass spectrometry. Dent Mater 2015;31:711-720.

32. Lazarchik DA, Hammond BD, Sikes CL, Looney SW, Rueggeberg FA. Hardness comparison of bulk-filled/transtooth and incremental-filled/ occlusally irradiated composite resins. J Prosthet Dent 2007;98:129140.

33. Machado FW, Borges FB, Cenci MS, Moraes RR, Boscato N. Effect of filling technique on the bond strength of methacrylate and siloranebased composite restorations. Braz Oral Res 2016;30:e44.

Received May 27, 2017 Accepted 29 August 2017 